\title{
Komunikasi Keprotokolan dalam Pelaksanaan Upacara Wisuda di Universitas Padjadjaran
}

\author{
Siti Intan Ratna Dewi ${ }^{{ }^{*}}$, Diah Karima Dewi ${ }^{2}$, Marlia ${ }^{3}$ \\ ${ }^{1,2,3}$ Direktorat Tata Kelola dan Komunikasi Publik, Universitas Padjadjaran, Bandung, Indonesia \\ intan@unpad.ac.id \\ Protocol Communication of Graduation Ceremony at Padjajaran University
}

\begin{abstract}
Every institution requires a protocol in their formal events as respect and appreciation for each actor or entity who involved in. As a State University, Padjadjaran University has many formal events that are attended by high-ranking government officials and other leaders, both leaders of Indonesian or abroad universities and also non-university leaders. The protocol team routinely carries out preparatory activities and coordinates with various relevant directorates at each event. This study was conducted to determine the lack of a protocol's role in carrying out graduation ceremonies that are carried out routinely as evaluation material. The method used is descriptive statistics using an instrument in the form of a questionnaire. The instrument design is divided into four groups of questions related to protocols, namely Protocol Attitude, Layout, Honor, and Ceremony. The survey results from the questionnaire were analysed using descriptive and comparative analysis resulting in several shortcomings in the Ceremonial Procedure that could be seen from the results of respondents' responses which tended to be negative. Therefore, efforts must be made to increase some of the activities in the implementation of the Ceremony at the Graduation Ceremony of the University of Padjadjaran.
\end{abstract}

Keywords: Protocol Communication; Graduation Ceremony; Universitas Padjadjaran

\begin{abstract}
ABSTRAK
Setiap instansi memerlukan protokol dalam setiap acara ataupun kegiatan sebagai penghormatan dan penghargaan pada setiap individu maupun entitas yang terlibat di dalamnya. Universitas Padjadjaran sebagai Perguruan Tinggi Negeri Badan Hukum memiliki banyak kegiatan dan acara resmi yang dihadiri oleh para pejabat tinggi pemerintah, para pejabat atau pimpinan lainnya, pimpinan sesama perguruan Tinggi dalam dan luar negeri maupun non-perguruan tinggi. Tim protokoler secara rutin melakukan kegiatan persiapan, perencanaan dan berkoordinasi dengan berbagai direktorat terkait pada setiap acara. Penelitian ini dilakukan untuk mengetahui kekurangan peran protokoler dalam menjalankan upacara wisuda yang dilaksanakan secara rutin sebagai bahan evaluasi. Metode yang digunakan adalah survei dengan analisis statisitik deskriptif. Instrumen penelitian adalah kuesioner yang terbagi atas 4 kelompok pertanyaan yang berkaitan dengan keprotokolan yaitu Sikap Keprotokolan, Tata Tempat, Tata Penghormatan, dan Tata Upacara. Data dianalisis dengan analisis statistik deskriptif dan komparatif. Hasil penelitian menunjukkan bahwa terdapat beberapa kekurangan pada Tata Upacara yang terlihat dari hasil jawaban responden yang sebagian besar cenderung negatif. Oleh karena itu harus ada upaya meningkatkan beberapa kegiatan dalam pelaksanaan Tata Upacara Wisuda di Universitas Padjadjaran.
\end{abstract}

Kata Kunci: Komunikasi Keprotokolan; Upacara Wisuda; Universitas Padjajaran

*corresponding author

Acceptance: $29-01-2020$

Revision: 27-01-2020 Published online: 30-01-2020

JCommsci Vol. 3, No. 1, 2020, hlm. 26 - 38 


\section{PENDAHULUAN}

Setiap instansi memerlukan protokol dalam setiap acara ataupun kegiatan, terutama karena berkaitan dengan kehormatan dan penghargaan pada setiap pelaku individu maupun entitas yang terlibat di dalam suatu kegiatan. Kedudukan protokol ini sangat penting hingga diterbitkannya Undang-undang tentang Undang-undang No. 9 Tahun 2010 tentang Keprotokolan yang mengatur tata tempat, tata upacara, dan tata penghormatan serta Peraturan Pemerintah No.62 tahun 1990 Tentang Ketentuan Keprotokolan Mengenai Tata Tempat, Tata Upacara, dan Tata Penghormatan.

Seiring meningkatnya aktivitas lembaga, meningkat pula kepedulian akan etiket dan tata cara penyelenggaraan acara, termasuk protokoler terutama pada kegiatan-kegiatan penting yang dikemas dalam sebuah acara seremonial. Penyelenggaraan acara yang sukses mempengaruhi kredibilitas penyelenggara termasuk kegiatan seremonial di perguruan tinggi (Siswanto, Wismanto, Ulumuddin, \& Indrariani, 2013).

Universitas Padjadjaran sebagai Perguruan Tinggi Negeri Badan Hukum sarat akan aktivitas dan/atau kegiatan yang sifatnya resmi dan dihadiri oleh para pejabat tinggi pemerintah maupun para pejabat/pimpinan lainnya, baik pimpinan sesama perguruan Tinggi dalam dan/atau luar negeri maupun non-perguruan tinggi yang tentunya memiliki relasi dengan Universitas Padjadjaran dalam suatu acara resmi. Salah satu Peraturan Rektor Universitas Padjadjaran menyatakan bahwa agar pelaksanaan kegiatan yang berhubungan dengan keprotokolan dapat berlangsung lebih teratur, tertib, aman, lancar, efektif dan efisien sesuai dengan rangkaian acara yang telah ditetapkan dan kaidah peraturan perundang-undangan yang berlaku (Peraturan Rektor Nomor 55 Tahun 2016).

Pada setiap penyelenggaraan acara-acara resmi di Universitas Padjadjaran, tim protokoler sudah rutin melakukan persiapan/perencanaan jauh hari sebelumnya dan berkoordinasi dengan berbagai direktorat terkait, akan tetapi masih muncul kendala atau sesuatu hal yang terjadi di luar rencana. Permasalahan dalam pelaksanaan keprotokolan, tersebut misalnya terjadi dalam kegiatan Upacara Wisuda yang cukup menarik untuk dikaji dan diteliti penyebabnya.

Keprotokolan adalah serangkaian kegiatan yang berkaitan dengan aturan dalam acara kenegaraan atau acara resmi yang meliputi Tata Tempat, Tata Upacara, dan Tata Penghormatan sebagai bentuk penghormatan kepada seseorang sesuai dengan jabatan dan/atau kedudukannya dalam negara, pemerintahan, atau masyarakat (UU No. 9 Tahun 2010). Keprotokolan biasa melekat pada kegiatan acara kenegaraan ataupun acara resmi. Acara Kenegaraan adalah acara yang diatur dan dilaksanakan oleh panitia negara secara terpusat, dihadiri oleh Persiden dan/atau Wakil Presiden, serta Pejabat Negara dan undangan lain. Sedangkan Acara Resmi adalah acara yang diatur dan dilaksanakan oleh pemerintah atau lembaga negara dalam melaksanakan tugas dan fungsi tertentu dan dihadiri oleh Pejabat Negara dan/atau Pejabat Pemerintahan serta undangan lain (UU No. 9 Tahun 2010). 
Protokol itu penting, di antaranya karena pimpinan mempunyai hak untuk dihormati, baik di dalam maupun di luar kantor. Kata protokol itu sendiri dalam Bahasa Indonesia mulamula diartikan sebagai tata tertib pergaulan internasional atau sopan santun diplomatik. Dari pengertian ini kemudian berkembang sehingga istilah protokol diterapkan juga untuk upacaraupacara yang meliputi segala bentuk pertemuan, baik yang bersifat nasional maupun internasional, dan juga upacara yang resmi maupun yang setengah resmi, kenegaraan maupun sosial kemasyarakatan (Suyuti, 2002). Semua hal yang mengatur pelaksanaan suatu kegiatan disebut dengan istilah protokoler.

Protokoler itu bersifat dinamis, bisa mengalami perubahan karena berdasarkan hal-hal yang terjadi di lapangan dan karakter pimpinan masing-masing. Ada pimpinan yang simpel, sederhana, bahkan ada yang sulit untuk mengikuti protokol. Namun semua pimpinan harus mendapat penilaian yang sama, tidak boleh dibeda-bedakan. Adapun Ruang lingkup keprotokolan menurut Peraturan Pemerintah tentang Ketentuan Keprotokolan Mengenai Tata Tempat, Tata Upacara, dan Tata Penghormatan, yang menyatakan bahwa dalam rangka pelaksanaan ketentuan Pasal 4, 5, 6, dan 8 Undang-undang Nomor 8 Tahun 1987 Tentang Protokoler dipandang perlu mengatur tata tempat, tata upacara, dan tata penghormatan bagi pejabat negara, Pejabat Pemerintah, dan Tokoh Masyarakat tertentu dalam acara kenegaraan atau acara resmi dengan Peraturan Pemerintah.

Keprotokolan diatur berdasarkan pada asas kebangsaan, ketertiban dan kepastian hukum, keseimbangan, keserasian, dan keselarasan, serta timbal balik. Pengaturan keprotokolan bertujuan untuk memberikan penghormatan kepada Pejabat Negara, Pejabat Pemerintahan, Perwakilan Negara Asing dan/atau organisasi internasional, serta tokoh masyarakat tertentu, dan/atau tamu negara sesuai dengan kedudukan dalam negara, pemerintahan, dan masyarakat; memberikan pedoman penyelenggaraan suatu acara agar berjalan tertib, rapi, Lancar, dan teratur sesuai dengan ketentuan dan kebiasaan yang berlaku, baik secara nasional maupun internasional; dan menciptakan hubungan baik dalam tata pergaulan antar bangsa.

Penjabaran dari Peraturan Pemerintah tentang Ketentuan Keprotokolan Mengenai Tata Tempat, Tata Upacara, dan Tata Penghormatan di lingkungan Universitas Padjadjaran dalam penyelenggaraan acara resmi yang melibatkan unit protokoler(Peraturan Pemerintah (PP) No. 62 Tahun 1990, 1990). Kegiatan keprotokolan ini memiliki lingkup yang cukup luas, salah satunya adalah kegiatan Upacara Wisuda. Kegiatan Upacara Wisudan inilah menjadi fokus, dimana upacara wisuda ini diselenggarakan dan dipimpin oleh Rektor dalam rangka melantik Wisudawan. Wisudawan adalah lulusan Universitas Padjadjaran yang dinyatakan telah memenuhi syarat untuk mengikuti pelaksanaan wisuda. Upacara Wisuda ini dilaksanakan sebanyak-banyaknya 4 (empat) kali gelombang kelulusan dalam 1 (satu) tahun akademik. Adapun prosesi Upacara Wisuda ini setiap gelombangnya diikuti oleh Pimpinan Prosesi, Anggota Prosesi, Wisudawan, dan Undangan Prosesi Upacara Wisuda. Dengan melihat begitu 
banyaknya jumlah orang yang terlibat dalam kegiatan upacara wisuda, tentunya tim protokoler harus sudah siap menghadapi masalah yang mungkin timbul, baik pada sebelum kegiatan yaitu pada saat persiapan ataupun setelah kegiatan yaitu pada tahap pelaksanaan. Adapun beberapa masalah atau kendala yang seringkali terjadi pada pelaksanaan kegiatan upacara wisuda adalah pada tahap persiapan dan tahap pelakasanaannya.

\section{METODE}

Metode yang digunakan dalam penelitian ini adalah metode deskriptif. Penelitian deskriptif ini bertujuan untuk mendeskripsikan apa-apa yang selama ini berlaku. Di dalamnya terdapat upaya mendeskripsikan, mencatat, menganalisis, dan menginterpretasikan kondisi yang sekarang ini terjadi atau ada (Mardalis, 1999). Metode deskriptif merupakan suatu metode dalam pencarian fakta status sekelompok manusia, suatu obyek, suatu kondisi, suatu sistem pemikiran ataupun suatu peristiwa pada masa sekarang dengan interpretasi yang tepat (Sedarmayanti \& Hidayat, 2011).

Penelitian deskriptif dirancang untuk mengumpulkan informasi tentang keadaankeadaan nyata sekarang yang sementara berlangsung. Pada hakikatnya penelitian deskriptif adalah suatu metode untuk meneliti status sekelompok manusia, suatu objek dengan tujuan membuat deskripsi, gambaran, atau lukisan secara sistematis, faktual dan akurat mengenai fakta-fakta atau fenomena yang diselidiki. Analisis data merupakan kegiatan setelah data dari seluruh responden terkumpul (Sugiyono, 2013). Analisis data ini dilakukan dengan maksud untuk mempermudah penyajian data dan mudah untuk dipahami. Untuk menganalisis data yang diperoleh melalui penyebaran kuesioner/angket, analisis datanya menggunakan pendekatan deskriptif kuantitatif. Di dalam menyajikan data per item pernyataan ataupun per indikator, pertama-tama penulis menggunakan garis kontinum dan persentasi, sesuai dengan penjelasan yang dikemukakan bahwa: "Data yang diperoleh dari responden dapat diilustrasikan dengan garis kontinum" (Sugiyono, 2013).

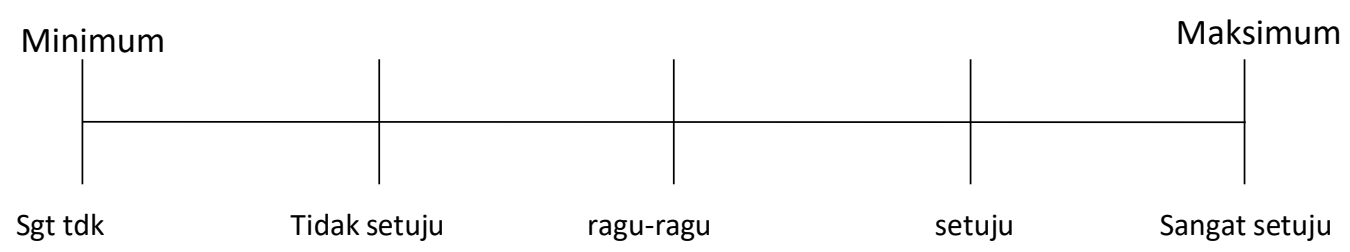

Gambar 1. Garis kontinum sebagai nilai indeks pertanyaan responden

Untuk keperluan analisis jawaban dari responden berupa nilai skor dapat dianalogkan sebagai berikut :
a. $\quad$ Alternatif jawaban 5 (SS) berada pada daerah sangat baik
b. Alternatif jawaban 4 (S) berada pada daerah baik
c. Alternatif jawaban $3(\mathrm{RR})$ berada pada daerah cukup baik
d. Alternatif jawaban 2 (TS) berada pada daerah kurang baik
e. Alternatif jawaban 1 (STS) berada pada daerah tidak baik 
Jenis penelitian ini adalah kualitatif dengan metode deskriptif. Analisa data dalam penelitian dengan kualitatif pada prinsipnya berproses secara induksi interpretasikonseptualisasi (Hamidi, 2005). Pengambilan data riset ini menggunakan kuesioner. Prosedur penyusunan kuesioner ini sendiri yaitu merumuskan tujuan yang akan dicapai dengan kuesioner, mengidentifikasikan variabel yang akan dijadikan sasaran kuesioner, menjabarkan setiap variabel menjadi sub-variabel yang lebih spesifik dan tunggal, menentukan jenis data yang akan dikumpulkan, sekaligus untuk menentukan teknik analisisnya (Aedi, 2010). Kuesioner yang digunakan merupakan kuesioner dengan skala bertingkat, dimana jawaban responden dilengkapi dengan pernyataan bertingkat yang menunjukkan skala sikap yang mencakup rentang dari sangat setuju sampai sangat tidak setuju terhadap pernyataannya.

Jumlah sample yang digunakan terdiri dari beberapa golongan yang mewakili dari berbagai kalangan dalam upacara wisuda. Teknik Snowball sampling digunakan dalam pengambilan data pada riset ini, yaitu teknik penentuan sampel yang mula - mula jumlahnya kecil, kemudian membesar. Penetapan ukuran sampel dari populasi menggunakan rumus Slovin, dimana penetapan sampel mempertimbangkan batas ketelitian yang dapat mempengaruhi kesalahan pengambilan sampel populasi.

\section{HASIL DAN PEMBAHASAN}

Hasil survey dengan menyebarkan kuesioner pada peserta Wisuda Gelombang IV, berdasarkan pada instrumen pertanyaan-pertanyaan yang berkaitan dengan keprotokolan. Daftar pertanyaan merupakan kisi-kisi yang dibuat untuk menggambarkan semua variabel yang akan diukur, dilengkapi dengan semua kemungkinan sumber data, semua metode dan instrumen yang mungkin dapat dipakai. Pertanyaan-pertanyaan yang termuat di dalam kisi-kisi ini merupakan rancangan ideal.

Kuesioner yang disebar pada Upacara Wisuda Gelombang IV ini menghasilkan jawabanjawaban yang beragam dari responden sebanyak 104 (seratus empat) orang. Instrumen pertanyaan dikelompokkan menjadi 4 (empat) kelompok dengan maksud untuk mengetahui tanggapan dari para responden dalam menilai sikap protokoler ( 9 pertanyaan), tata tempat ( 9 pertanyaan), tata upacara (12 pertanyaan), dan tata penghormatan (5 pertanyaan) dalam Upacara Wisuda Gelombang IV Tahun Akademik 2017/2018 di Universitas Padjadjaran. Dari hasil survey tersebut dapat dilihat bahwa ada perbedaan prosentase nilai yang diberikan oleh para responden. Hasil rata-rata penilaian responden menjadi hal yang penting untuk diurutkan dengan prosentase nilai dari yang tertinggi hingga yang terendah untuk analisis deksriptif penjelasan dalam menjelaskan keadaan pada upacara wisuda ini. 
Tabel 1. Jawaban responden pada kelompok pertanyaan Sikap Keprotokolan.

\begin{tabular}{lllllllll}
\hline NO & PERTANYAAN & STS & TS & R & S & SS & $(-)$ & $(+)$ \\
\hline 1 & $\begin{array}{l}\text { Protokoler sopan dan ramah dalam } \\
\text { memberikan pelayanan kepada Saudara }\end{array}$ & $0.0 \%$ & $0.0 \%$ & $0.0 \%$ & $51.9 \%$ & $48.1 \%$ & $0.0 \%$ & $100.0 \%$ \\
2 & $\begin{array}{l}\text { Protokoler berpenampilan baik dan rapi } \\
\text { Protokoler yang bertugas sebagai }\end{array}$ & $0.0 \%$ & $0.0 \%$ & $0.0 \%$ & $52.9 \%$ & $47.1 \%$ & $0.0 \%$ & $100.0 \%$ \\
\hline & $\begin{array}{l}\text { Pembawa Acara sangat jelas dalam } \\
\text { menyampaikan setiap detil acara }\end{array}$ & $0.0 \%$ & $0.0 \%$ & $1.9 \%$ & $47.1 \%$ & $51.0 \%$ & $1.9 \%$ & $98.1 \%$ \\
\hline $\begin{array}{l}\text { Protokoler yang bertugas sebagai } \\
\text { pemandu wisudawan sangat membantu } \\
\text { kelancaran jalannya upacara wisuda }\end{array}$ & $1.9 \%$ & $0.0 \%$ & $1.9 \%$ & $49.0 \%$ & $47.1 \%$ & $3.8 \%$ & $96.2 \%$ \\
\hline $\begin{array}{l}\text { Protokoler cepat tanggap dalam } \\
\text { memberikan pelayanan kepada Saudara }\end{array}$ & $0.0 \%$ & $1.9 \%$ & $4.8 \%$ & $54.8 \%$ & $38.5 \%$ & $6.7 \%$ & $93.3 \%$ \\
\hline $\begin{array}{l}\text { Protokoler yang mengatur barisan } \\
\text { prosesi Guru Besar bekerja dengan baik }\end{array}$ & $0.0 \%$ & $0.0 \%$ & $6.7 \%$ & $47.1 \%$ & $46.2 \%$ & $6.7 \%$ & $93.3 \%$ \\
$\begin{array}{l}\text { Protokoler dapat memberikan jawaban } \\
\text { atas pertanyaan atau dapat }\end{array}$ & $\begin{array}{l}\text { memberikan informasi dengan } \\
\text { memuaskan }\end{array}$ & $0.0 \%$ & $0.0 \%$ & $7.7 \%$ & $55.8 \%$ & $36.5 \%$ & $7.7 \%$ & $92.3 \%$ \\
\hline $\begin{array}{l}\text { Protokoler yang mengatur kedatangan } \\
\text { orangtua wisudawan telah bekerja } \\
\text { dengan baik }\end{array}$ & $1.9 \%$ & $1.9 \%$ & $3.8 \%$ & $54.8 \%$ & $37.5 \%$ & $7.7 \%$ & $92.3 \%$ \\
\hline $\begin{array}{l}\text { Protokoler sangat membantu dalam } \\
\text { mengatur sesi foto bersama }\end{array}$ & $0.0 \%$ & $0.0 \%$ & $8.7 \%$ & $43.3 \%$ & $48.1 \%$ & $8.7 \%$ & $91.3 \%$ \\
\hline
\end{tabular}

Tabel 2. Jawaban responden pada kelompok pertanyaan Tata Tempat

\begin{tabular}{|c|c|c|c|c|c|c|c|c|}
\hline NO & PERTANYAAN & STS & TS & $\mathbf{R}$ & $\mathrm{S}$ & SS & $(-)$ & $(+)$ \\
\hline 1 & $\begin{array}{l}\text { Pengaturan tempat duduk para } \\
\text { wisudawan sudah sesuai dan tersusun } \\
\text { dengan baik dan rapi }\end{array}$ & $0.0 \%$ & $0.0 \%$ & $4.8 \%$ & $39.4 \%$ & $55.8 \%$ & $4.8 \%$ & $95.2 \%$ \\
\hline 2 & $\begin{array}{l}\text { Pengaturan tempat duduk Rektor dan } \\
\text { para Pimpinan di atas } \\
\text { Podium/Panggung dengan baik dan } \\
\text { rapi }\end{array}$ & $0.0 \%$ & $0.0 \%$ & $4.8 \%$ & $44.2 \%$ & $51.0 \%$ & $4.8 \%$ & $95.2 \%$ \\
\hline 3 & Pengaturan Suara (Soundsystem) & $0.0 \%$ & $0.0 \%$ & $4.8 \%$ & $51.0 \%$ & $44.2 \%$ & $4.8 \%$ & $95.2 \%$ \\
\hline 4 & $\begin{array}{l}\text { Pengaturan tempat duduk wisudawan } \\
\text { dan undangan VIP udah tersusun } \\
\text { dengan baik dan rapi }\end{array}$ & $0.0 \%$ & $0.0 \%$ & $5.8 \%$ & $48.1 \%$ & $46.2 \%$ & $5.8 \%$ & $94.2 \%$ \\
\hline 5 & $\begin{array}{l}\text { Pengaturan tempat para pengisi acara } \\
\text { sudah baik }\end{array}$ & $0.0 \%$ & $1.0 \%$ & $4.8 \%$ & $53.8 \%$ & $40.4 \%$ & $5.8 \%$ & $94.2 \%$ \\
\hline 6 & $\begin{array}{l}\text { Pengaturan Tata Lampu (lighting) } \\
\text { Pengaturan tempat duduk orangtua }\end{array}$ & $0.0 \%$ & $0.0 \%$ & $6.7 \%$ & $52.9 \%$ & $40.4 \%$ & $6.7 \%$ & $93.3 \%$ \\
\hline 7 & $\begin{array}{l}\text { wisudawan sudah tersusun dengan } \\
\text { baik dan rapi } \\
\text { Pengaturan tempat duduk para Ketua }\end{array}$ & $0.0 \%$ & $1.0 \%$ & $6.7 \%$ & $54.8 \%$ & $37.5 \%$ & $7.7 \%$ & $92.3 \%$ \\
\hline 8 & $\begin{array}{l}\text { Prodi sudah tersusun dengan baik dan } \\
\text { rapi }\end{array}$ & $0.0 \%$ & $1.0 \%$ & $11.5 \%$ & $47.1 \%$ & $40.4 \%$ & $12.5 \%$ & $87.5 \%$ \\
\hline 9 & $\begin{array}{l}\text { Pengaturan tempat duduk Dharma } \\
\text { Wanita dan undangan VVIP tersusun } \\
\text { dengan baik dan rapi }\end{array}$ & $0.0 \%$ & $0.0 \%$ & $13.5 \%$ & $50.0 \%$ & $36.5 \%$ & $13.5 \%$ & $86.5 \%$ \\
\hline
\end{tabular}


Tabel 3. Jawaban responden pada kelompok pertanyaan Tata Upacara

\begin{tabular}{|c|c|c|c|c|c|c|c|c|}
\hline NO & PERTANYAAN & STS & TS & $\mathbf{R}$ & $\mathbf{S}$ & SS & $(-)$ & $(+)$ \\
\hline 1 & $\begin{array}{l}\text { Susunan acara dalam Upacara wisuda } \\
\text { tersusun dengan baik dan rapi }\end{array}$ & $1.0 \%$ & $1.0 \%$ & $1.0 \%$ & $56.7 \%$ & $40.4 \%$ & $2.9 \%$ & $97.1 \%$ \\
\hline 2 & $\begin{array}{l}\text { Saudara menyukai dan menikmati } \\
\text { seluruh rangkaian acara }\end{array}$ & $0.0 \%$ & $0.0 \%$ & $4.8 \%$ & $62.5 \%$ & $32.7 \%$ & $4.8 \%$ & $95.2 \%$ \\
\hline 3 & $\begin{array}{l}\text { Upacara dimulai tepat pada waktunya } \\
\text { sesuai jadwal yang telah ditetapkan }\end{array}$ & $1.9 \%$ & $1.0 \%$ & $3.8 \%$ & $48.1 \%$ & $45.2 \%$ & $6.7 \%$ & $93.3 \%$ \\
\hline 4 & $\begin{array}{l}\text { Upacara wisuda berlangsung dengan } \\
\text { khidmat, tertib, dan lancar }\end{array}$ & $0.0 \%$ & $0.0 \%$ & $6.7 \%$ & $54.8 \%$ & $38.5 \%$ & $6.7 \%$ & $93.3 \%$ \\
\hline 5 & Acara hiburan (nyanyian dan tarian) & $0.0 \%$ & $0.0 \%$ & $7.7 \%$ & $43.3 \%$ & $49.0 \%$ & $7.7 \%$ & $92.3 \%$ \\
\hline 6 & $\begin{array}{l}\text { Selama upacara berlangsung Saudara } \\
\text { merasa cukup nyaman }\end{array}$ & $0.0 \%$ & $0.0 \%$ & $7.7 \%$ & $57.7 \%$ & $34.6 \%$ & $7.7 \%$ & $92.3 \%$ \\
\hline 7 & $\begin{array}{l}\text { Selingan acara hiburan yang } \\
\text { ditampilkan sangat menarik }\end{array}$ & $0.0 \%$ & $0.0 \%$ & $16.3 \%$ & $56.7 \%$ & $26.9 \%$ & $16.3 \%$ & $83.7 \%$ \\
\hline 8 & $\begin{array}{l}\text { Persembahan bunga dari wisudawan } \\
\text { kepada orangtua }\end{array}$ & $0.0 \%$ & $0.0 \%$ & $17.3 \%$ & $52.9 \%$ & $29.8 \%$ & $17.3 \%$ & $82.7 \%$ \\
\hline 9 & Sesi Foto Bersama & $0.0 \%$ & $0.0 \%$ & $17.3 \%$ & $52.9 \%$ & $29.8 \%$ & $17.3 \%$ & $82.7 \%$ \\
\hline 10 & $\begin{array}{l}\text { Jadwal Upacara Wisuda sudah sesuai } \\
\text { dengan kalender akademik }\end{array}$ & $1.0 \%$ & $4.8 \%$ & $13.5 \%$ & $41.3 \%$ & $39.4 \%$ & $19.2 \%$ & $80.8 \%$ \\
\hline 11 & $\begin{array}{l}\text { Prosesi pemanggilan wisudawan ke } \\
\text { panggung }\end{array}$ & $0.0 \%$ & $1.9 \%$ & $18.3 \%$ & $50.0 \%$ & $29.8 \%$ & $20.2 \%$ & $79.8 \%$ \\
\hline 12 & $\begin{array}{l}\text { Upacara selesai/berakhir sesuai jadwal } \\
\text { yang telah ditetapkan }\end{array}$ & $1.9 \%$ & $8.7 \%$ & $15.4 \%$ & $44.2 \%$ & $29.8 \%$ & $26.0 \%$ & $74.0 \%$ \\
\hline
\end{tabular}

Tabel 4. Jawaban responden pada kelompok pertanyaan Tata Penghormatan

\begin{tabular}{lllllllll}
\hline NO & PERTANYAAN & STS & TS & R & S & SS & $(-)$ & $(+)$ \\
\hline 1 & $\begin{array}{l}\text { Penghormatan terhadap Bendera Merah Putih } \\
\text { sudah sesuai dengan undang-undang dan aturan } \\
\text { yang berlaku }\end{array}$ & $0.0 \%$ & $0.0 \%$ & $3.8 \%$ & $50.0 \%$ & $46.2 \%$ & $3.8 \%$ & $96.2 \%$ \\
2 & $\begin{array}{l}\text { Penghormatan terhadap lagu kebangsaan } \\
\text { Indonesia Raya dilaksanakan dengan baik sesuai } \\
\text { dengan undang-undang dan aturan yang berlaku }\end{array}$ & $1.0 \%$ & $0.0 \%$ & $3.8 \%$ & $50.0 \%$ & $45.2 \%$ & $4.8 \%$ & $95.2 \%$ \\
3 & $\begin{array}{l}\text { Penghormatan terhadap Guru Besar tamu yang } \\
\text { ikut prosesi sangat baik }\end{array}$ & $0.0 \%$ & $2.9 \%$ & $5.8 \%$ & $50.0 \%$ & $41.3 \%$ & $8.7 \%$ & $91.3 \%$ \\
4 & $\begin{array}{l}\text { Penghormatan kepada tamu undangan VIP dan } \\
\text { VVIP yang hadir sangat baik }\end{array}$ & $0.0 \%$ & $2.9 \%$ & $5.8 \%$ & $50.0 \%$ & $41.3 \%$ & $8.7 \%$ & $91.3 \%$ \\
\hline & $\begin{array}{l}\text { Penghormatan terhadap Lambang Negara sudah } \\
\text { sesuai dengan undang-undang dan aturan yang } \\
\text { berlaku }\end{array}$ & $1.0 \%$ & $0.0 \%$ & $14.4 \%$ & $39.4 \%$ & $45.2 \%$ & $15.4 \%$ & $84.6 \%$ \\
\hline
\end{tabular}

Trend adalah suatu gerakan (kecenderungan) naik atau turun dalam jangka panjang, yang diperoleh dari rata-rata perubahan dari waktu ke waktu. Rata-rata perubahan tersebut bisa bertambah bisa berkurang. Jika rata-rata perubahan bertambah disebut trend positif atau trend mempunyai kecenderungan naik. Sebaliknya, jika rata-rata perubahan berkurang disebut trend negatif atau trend yang mempunyai kecenderungan menurun (Maryati, 2010). 
Dari hasil survey yang dilakukan pada penelitian ini terlihat bahwa ada perbedaan prosentase nilai yang diberikan oleh para responden. Hasil rata-rata penilaian responden menjadi hal yang penting untuk diurutkan dengan prosentase nilai dari yang tertinggi hingga yang terendah untuk analisis deksriptif penjelasan dalam menjelaskan keadaan pada upacara wisuda ini. Pengurutan dalam persentase nilai positif ini dimaksudkan agar dapat mengerucutkan hasil survei dan menunjukkan gejala-gejala yang timbul sebagai kendala pada upacara wisuda ini. Gejala yang timbul ini dapat dilihat dari prosentase nilai negatif yang diberikan oleh responden dan berpotensi menjadi kendala-kendala yang harus disikapi dengan analisa kualitatif selanjutnya. Adapun urutan kelompok pertanyaan berdasarkan pada nilai positif adalah sebagai berikut :

Tabel 5. Trend negatif dan positif dalam ke-4 kelompok pertanyaan keprotokolan dalam upacara wisuda.

\begin{tabular}{llll}
\hline NO & KELOMPOK PERTANYAAN & Negatif & Positif \\
\hline 1 & Sikap Keprotokolan & $4.8 \%$ & $95.2 \%$ \\
2 & Tata Tempat & $7.4 \%$ & $92.6 \%$ \\
3 & Tata Penghormatan & $9.0 \%$ & $91.0 \%$ \\
4 & Tata Upacara & $12.7 \%$ & $87.3 \%$ \\
\hline
\end{tabular}

\section{Analisis trend positif pada Upacara Wisuda}

Penampilan seorang protokol pada dasarnya merupakan cerminan dari institusi yang diwakilinya, sehingga protokol dianggap sebagai wajah institusi. Protokol selalu berhubungan dengan pihak ketiga, oleh karena itu seorang protokoler harus mempunyai kepribadian terbaik karena merupakan ujung tombak terdepan. Keberhasilan tugas protokol sangat ditentukan oleh perencanaan yang matang, koordinasi dan komunikasi yang baik dengan berbagai pihak terkait, dan pelaksanaan yang mantap utamanya pada penyusunan acara mulai dari tahap awal/persiapan, pelaksanaan hingga akhir kegiatan (Imron, 2018).

Sikap protokoler dalam memberikan pelayanan kepada para peserta wisuda dan orang tua atau keluarga wisudawan/wati dinilai baik. Hal ini terlihat dari respon para wisudawan dalam memberikan penilaian terhadap pertanyaan sikap para protokoler dengan hasil positif, yaitu $100 \%$ setuju dan sangat setuju dalam menilai sikap para protokoler tersebut. Pelayanan yang ramah dan sopan ini sudah seharusnya menjadi ciri dan karakter utama para protokoler Universitas Padjadjaran dalam melaksanakan tugas-tugas keprotokolan di setiap acara resmi dalam hal ini acara wisuda. Meskipun penilaian para responden $100 \%$ positif tapi $51.9 \%$ Setuju sehingga perlu ada peningkatan dalam pelayanan protokoler agar lebih baik.

Begitu pula dengan penampilan dan kerapihan dinilai $100 \%$ positif dengan $52.9 \%$ Setuju sehingga diharapkan untuk meningkatkan penampilan agar semakin baik. Sedangkan sikap protokoler pada pembawa acara, memandu acara wisuda, dinilai sudah baik dengan sedikitnya responden yang memberikan nilai positif di atas 95\% dan nilai negatif yakni di bawah $5 \%$. 
Respon negatif ini mayoritas menilai ragu-ragu sehingga masih relatif baik dalam pelayanan para protokoler ini. Peningkatan perlu dilakukan baik dalam membawakan acara ataupun memandu acara yang memerlukan latihan pra acara (gladi resik) agar lebih siap dalam penyelenggaraan acara, dan strategi komunikasi yang lebih baik pada saat acara.

Tata Tempat menunjukkan adanya trend positif yang dilihat pada pertanyaanpertanyaan yang termasuk pada kategori sangat baik dan kategori baik. Pertanyaan dengan respon yang positif pada kategori sangat baik dengan penilaian antara $95-100 \%$ adalah pada pengaturan tempat duduk wisudawan yang sudah tersusun baik dan rapi (95.2\%), pengaturan tempat duduk rektor dan pimpinan (95.2\%), serta pengaturan suara (95.2\%). Hal ini dikarenakan pengaturan tempat duduk ini sudah menjadi aturan yang baku sehingga protokoler sudah bisa menjalankan pengaturan tempatnya dengan sangat baik. Adapun nilai respon negatif sebanyak $4.8 \%$ diberikan dengan nilai ragu yang tidak menjadi kekurangan pada respon kelompok Tata Tempat ini. Sedangkan pada respon yang termasuk pada kategori baik dengan nilai $90-95 \%$ terlihat pada respon yang diberikan untuk pengaturan tempat duduk wisudawan dan VIP (94.2\%), tempat para pengisi acara (94.2\%), pengaturan tata lampu (93.3\%), dan pengaturan tempat duduk orang tua (92.3\%). Pada pengaturan tempat para pengisi acara terdapat respon negatif yang terdiri dari ragu $4.8 \%$ dan tidak setuju sebesar $1.0 \%$, selain itu pengaturan tempat duduk orang tua wisudawan pun memiliki respon negatif yang terdiri atas $6.7 \%$ ragu dan $1.0 \%$ tidak setuju. Hal ini menunjukkan bahwa ada sedikit kekurangan pada tata tempat para pengisi acara dan orang tua wisudawan sehingga perlu untuk ditinjau kembali agar lebih baik dalam pengaturannya.

Tata Penghormatan terbagi menjadi dua kategori dimana kategori baik sekali dan baik dan didominasi oleh penilaian para responded yang positif. Pada kategori baik sekali pertanyaan yang direspond positif adalah penghormatan terhadap bendara merah putih sebesar 96.2\% dan penghormatan terhadap lagu Indonesia Raya sebesar 95.2\%. Hal ini dikarenakan peran protokoler yang sudah mampu menerapkan aturan penghormatan sesuai dengan undang-undang serta aturan yang berlaku. Selain itu dalam setiap kegiatan formal tidak hanya pada upacara wisuda saja kedua hal ini diberlakukan. Selain itu, jawaban responden atas pertanyaan yang termasuk pada kategori baik yaitu penghormatan terhadap guru besar dan tamu VIP dan VVIP sangat baik, meskipun ada sedikit yang menilai negatif sebesar $8.7 \%$. Respond negatif ini perlu ditekan dengan cara peningkatan dengan komunikasi yang lebih baik untuk lebih memberikan penghormatan terhadap guru besar dan tamu upacara wisuda.

Penyajian susunan acara pada upacara wisuda ini, direspond positif sebanyak $97.1 \%$ yang terdiri atas $40.4 \%$ Sangat Setuju dan $56.7 \%$ Setuju. Selain itu peserta wisuda menikmati rangkaian acara wisuda dengan respond positif sebanyak $95.2 \%$ yang terdiri atas $32.7 \%$ Sangat Setuju dan 62.5\% Setuju. Dengan demikian susunan acara pada upacara wisuda sudah tertata dengan baik dan dapat dijadikan standar dalam penyelenggaraan upacara wisuda di Universitas Padjadjaran. 


\section{Analisis trend negatif pada Upacara Wisuda}

Kedisiplinan dalam waktu penyelenggaraan, kekhidamatan dan ketertibaan penyelenggaraan, acara hiburan, serta saat penyelenggaraan berlangsung, ada sedikit repond negatif sebesar $7.2 \%$ yang memerlukan peningkatan dalam pelaksanaannya sekalipun secara keseluruhan keempat penilaiaan ini masih memiliki respond yang baik yaitu sebesar $92.8 \%$. hal yang perlu dicermati adalah waktu memulai upacara wisuda masih mengalami keterlambatan dan perlu peningkatan dalam kedisiplinan untuk memamtuhi jadwal upacara.

Jawaban responden yang termasuk pada kategori cukup baik terdapat pada jawaban atas pertanyaan mengenai penampilan selingan acara hiburan dengan nilai positif $83.7 \%$, persembahan bunga $82.7 \%$, sesi foto bersama $82.7 \%$, dan kesesuaian antara jadwal wisuda dan kalender akademik 80.8\%. Akan tetapi dari 104 responden ini ada yang memberikan penilaian negatif diatas $10 \%$ pada masing-masing pertanyaan. Hal ini harus menjadi perhatian protokoler dimana ketiga hal ini berpotensi menjadi kendala jika tidak dilakukan pembenahan atau perbaikan untuk meningkatkan tata upacara ini.

Trend negatif pada Tata Upacara pada respon selingan acara hiburan. Pada selingan acara hiburan ini 104 responden memberikan nilai negatif sebanyak $16.3 \%$ yang teridentifikasi Ragu. Hal ini menyatakan bahwa acara hiburan yang ditampilkan sebagai selingan di upacara wisuda diinginkan oleh para peserta upacara wisuda, hanya acar yang tampilkan kurang menarik perhatian para peserta upacara wisuda sehingga banyak responden memberikan penilaian ragu. Mengingat acara selingan ini diperlukan sebagai acara hiburan atau selingan penghibur bagi perserta wisuda sehingga harus bersifat menghibur dan menurunkan tingkat kelelahan atau kebosanan dari peserta wisuda.

Hal yang harus diperhatikan sekali adalah kaitan kesesuaian antara jadwal pelaksanaan wisuda dengan kalender akademik. Dalam penjadwalan ini memang tidak mudah mengingat keputusan pelaksanaan upacara wisuda melibatkan beberapa pihak terkait tidak hanya unit protokoler saja atau direktorat tata kelola saja akan tetapi beberapa direktorat terkait dan keputusan pimpinan.

Ada dua jawaban dengan nilai respon negatif lebih dari $20 \%$ sehingga termasuk pada kategori kurang baik. Prosesi pemanggilan wisuda memiliki respon negatif sebesar $20.2 \%$ dan lamanya upacara wisuda memiliki respon negatif sebesar $26.0 \%$. Jika diperhatikan kedua hal ini saling terkait dimana lamanya waktu penyelesaian untuk upacara wisuda sangat terkait pada banyaknya peserta wisuda yang dipanggil ke panggung. Waktu yang diperlukan oleh seorang wisudawan untuk prosesi pemanggilan perlu dihitung ulang serta jumlah wisudawan pada setiap sesi, sehingga lama pelaksanaan diprediksi lebih tepat.

Selain itu, adanya acara-acara tambahan yang bisa menyebabkan penyelenggaraan acara wisuda terlambat selesai. Banyak faktor yang terkait terhadap waktu penyelenggaraan upacara wisuda ini, sehingga perlu untuk dikaji lebih dalam dan ditingkatkan baik pada perencanaannya ataupun pada pelaksanaannya. Secara detil trend negatif paling besar terletak 
pada komunikasi protokoler pada proses pemanggilan wisudawan yang membutuhkan waktu cukup lama sehingga mengakibatkan penyelesaian wisuda mengalami keterlambatan pada jadwal yang telah ditentukan.

Seorang protokoler selalu menjadi sorotan publik dalam setiap pelaksanaan suatu acara. Salah satu model yang dikembangkan adalah dengan menyimpan berbagai prosedur keprotokolan (SOP) pada suatu Portal Pengetahuan. Sehingga, apabila terjadi penggantian personalia bidang protokoler tidak akan mengurangi kualitas pekerjaan keprotokolan (Pathuloh, 2017). Keprotokolan cenderung merupakan dari tugas public relations. Secara umum tugas pokok Bagian Hubungan Masyarakat di wilayah kajian berkaitan dengan "menyelenggarakan penyusunan, perumusan kebijakan dan pengolahan informasi, penyebarluasan informasi, dokumentasi, pelaksanaan kegiatan dan acara bersifat protokoler, penyelenggaraan (Rahmat \& Bakti, 2016).

Peran public relations atau humas merupakan bentuk mengoptimalkan kerja humas yang bertugas untuk menciptakan, membangun, menigkatkan, mempertahankan citra dan mempublikasikan segala bentuk program kerja lembaga/instansi (Rini, Rusmiwari, \& Widodo, 2017). PR adalah jembatan yang membangun relasi yang baik dengan publik PR itu sendiri (Ratnasari, Rahmat, \& Prastowo, 2018). Citra dan Reputasi sebuah lembaga yang positif akan menunjang kinerja lembaga, Jika sebuah lembaga memiliki citra positif maka dukungan publik (Stakeholder) akan mengalir dengan sendirinya (Kasmirus, 2013). Pada lembaga perguruan tinggi, humas dan Protokoler adalah menjadi penghubung dengan pihak luar universitas (juru bicara universitas) (Fajri, 2017). Salah satu tugas protokoler di perguruan tinggi adalah menyelenggarakan upacara wisuda.

Penyelenggaraan acara/upacara sudah menjadi bagian dari kehidupan sehari-hari manusia yang berhubungan dengan peristiwa-peristiwa penting baik itu dengan kehidupan berbangsa, bernegara, bermasyarakat, berorganisasi maupun berkeluarga dalam berbagai sifat acara untuk berbagai macam tujuan (Hafizah, 2019). Salah satu tujuan upacara wisuda di perguruan tinggi, selain melakukan upacara kelulusan, adalah juga untuk menanamkan citra lembaga $d$ benak publik, termasuk publik orang tua mahasiswa yang menjadi publik eksternal bagi perguruan tinggi. Oleh karena itu PTN perlu melakukan evaluasi implementasi program public relations mengingat pentingnya evaluasi proses implementasi program public relations dalam era PT BHP sekarang ini untuk mendukung pemasaran jasa pendidikan di perguruan tinggi (Farouk, 2010) (Musyarrofah, 2018). Termasuk evaluasi tingkat kepuasan orang tua dalam mengikuti upacara wisuda kelulusan putra putrinya.

\section{SIMPULAN}

Komparasi antara trend positif dan trend negatif pada Kelompok Sikap Protokoler menghasilkan beberapa hal penting sebagai prioritas pengembangan sikap protokoler. Prioritas pertama adalah segi pengaturan baik pengaturan pada sesi foto bersama, pengaturan 
kedatangan orang tua wisudawan, dan pengaturan barisan prosesi guru besar. Dalam hal pengaturan perlu dipikirkan mengenai pengembangan strategi pada saat sesi foto bersama yang lebih efektif serta dapat dibuatkan teknis pelaksanaan dalam pengaturan acara wisuda pada setiap sesi, terutama sesi foto bersama. Selain itu perlu juga ditetapkan aturan-aturan secara baku dalam pengaturan barisan prosesi guru besar. Prioritas kedua adalah meningkatkan cara berkomunikasi bagi para protokoler untuk dapat memberikan penjelasan kepada para peserta acara wisuda, dan cepat tanggap dalam melayani berbagai pertanyaan atau pelayanan lain dalam kaitannya dengan acara wisuda. Prioritas ketiga adalah protokoler dapat mempersiapkan lebih baik untuk kesiapan dalam pelaksanaan acara wisuda secara detil, sehingga perlu tambahan baik latihan ataupun pemahaman dalam persiapan jadi penyelenggaraan acara wisuda.

Komparasi antara trend positif dan trend negatif pada Kelompok Tata Tempat menghasilkan beberapa hal yang harus dikembangkan yaitu pengaturan dan perhitungan jumlah prodi dalam setiap sesi pada acara wisuda, kajian yang lebih mendalam mengenai pentingnya keikutsertaan para Kaprodi dalam acara wisuda pada setiap sesinya, penataan tempat atau lokasi duduk para Kaprodi, Dharma wanita, dan VVIP agar lebih baik dalam setiap sesi acara wisuda. Ketiga hal ini menjadi prioritas utama dalam peningkatan dan pengembangan pada pengatruran tata tempat untuk acara wisuda di Universitas Padjadjaran. Sedangkan prioritas selanjutnya adalah pengaturan tempat duduk orang tua wisudawan yang perlu memperhitungkan aksesibilitas dan lokasi yang nyaman untuk para orang tua wisudawan, mengingat para orang tua yang sudah lanjut usia dan mengalami disabilitas yang menghadiri undangan acara wisuda.

Komparasi antara trend positif dan trend negatif pada Kelompok Tata Upacara menghasilkan beberapa hal penting yang dikaji lebih dalam dan memperbaiki beberapa hal agar kendala pada pelaksanaan upacara wisuda ini berkurang, yaitu perlunya menghitung waktu pelaksanaan wisuda dan jumlah wisudawan dalam hal lamanya prosesi pemanggilan wisudawan ke panggung, Ketegasan dalam penjadwalan penyelenggaraan upacara wisuda dan kepastiannya pada kalender akademik, adanya alternatif penampilan acara hiburan ebagai selingan di upacara wisuda, baik pentingnya acara itu ditampilkan atau acara apa yang lebih bisa menghibur pada peserta wisuda. Prioritas selanjutnya adalah meninjau ulang mekanisme teknis pada pelaksanaan sesi foto bersama dan persembahan bunga dari wisudawan kepada orangtua.

\section{Ucapan Terimakasih :}

Tulisan ini tersusun berdasarkan pada hasil riset mengenai Peran Protokol Dalam Pelaksanaan Upacara Wisuda di Universitas Padjadjaran pada Hibah Internal Unpad dengan Skema RTKU tahun 2018. 


\section{DAFTAR PUSTAKA}

Aedi, N. (2010). Instrumen Penelitian dan Pengumpulan Data. Bandung: Universitas Pendidikan Indonesia.

Fajri, C. (2017). Peran Humas Dalam Meningkatkan Loyalitas Stakeholders Universitas Ahmad Dahlan. Informasi: Kajian ilmu Komunikasi, 47(1), 97-108.

Farouk, U. (2010). Peran Public Relations Di Perguruan Tinggi Negeri (PTN) Dalam Era Badan Hukum Pendidikan Tinggi. Dialogue: Jurnal Ilmu Administrasi Dan Kebijakan Publik, 6(1), 68-77-77.

Hafizah, E. (2019). Implementasi Tata Laksana Pedoman Master Of Ceremony (MC) Bagi Siswa-Siswi Sekolah Dasar (Studi Kasus pada Siswa-Siswi Sekolah Dasar Alam Mahira Kota Bengkulu). AlHikmah, 13(1), 77. https://doi.org/10.24260/al-hikmah.v13i1.1336

Hamidi. (2005). Metode Penelitian Kualitatif. Malang: UMM Press.

Kasmirus, W. (2013). Peran Kehumasan dalam Membangun Citra Pemerintah. Jurnal Administrasi Reform, 1(1), 190-208.

Mardalis. (1999). Metode Penelitian Suatu Pendekatan Proposal. Jakarta: Bumi Aksara.

Maryati. (2010). Statistika Ekonomi dan Bisnis. Edisi Revisi. Yogyakarta: UPP AMPYKPN.

Musyarrofah, M. (2018). Peran Humas Dalam Pengembangan Pendidikan Tinggi. Idaarah: Jurnal Manajemen Pendidikan, 2(1), 11-23. https://doi.org/10.24252/idaarah.v2i1.5122

Pathuloh, A. (2017). Pengaruh Pelaksanaan Kebijakan Protokoler Kepala Daerah terhadap Koordinasi Keprotokolan dalam Mewujudkan Efektivitas Tugas-tugas Protokoler Kepala Daerah. Jurnal Publik, 11(1), 33-43.

Rahmat, A., \& Bakti, I. (2016). Kinerja Hubungan Masyarakat (Humas) Pemerintah daerah Kabupaten dan Kota di Jawa Barat. Jurnal Kajian Komunikasi, 4(2), 133-141.

Ratnasari, E., Rahmat, A., \& Prastowo, F. A. A. (2018). Peran Humas Perguruan Tinggi Negeri Badan Hukum dalam Implementasi Kebijakan Keterbukaan Informasi. PRofesi Humas: Jurnal IImiah Ilmu Hubungan Masyarakat, 3(1), 21. https://doi.org/10.24198/prh.v3i1.14034

Rini, K. S., Rusmiwari, S., \& Widodo, H. P. (2017). Peran humas dalam meningkatkan citra Universitas Tribhuwana Tunggadewi. JISIP: IImu Sosial Dan Ilmu Politik, 6(1), 34-37. Retrieved from https://publikasi.unitri.ac.id/index.php/fisip/article/view/369/302

Sedarmayanti, \& Hidayat, S. (2011). Metodologi Penelitian. Bandung: Mandar Maju.

Siswanto, Wismanto, A., Ulumuddin, A., \& Indrariani, E. A. (2013). Pengembangan Pelatihan Kepewaraan Bagi Warga Kelurahan Jatisari Kecamatan Ngaliyan Dalam Mendukung Percepatan Kota Layak Anak Di Kota Semarang Anak Di Kota Semarang. E-Dimas: Jurnal Pengabdian Kepada Masyarakat, 4(2), 45-55.

Sugiyono. (2013). Metode Penelitian Kuantitatif, Kualitatif dan R\&D. Bandung: Alfabeta.

Suyuti, A. (2002). Teknik Cepat Menjadi Orator, Da'i, dan MC Profesional. Pekalongan: Cinta IImu.

\section{Aturan Perundang-undangan}

Undang-undang (UU) No. 9 Tahun 2010. (2010). Keprotokolan.

Peraturan Pemerintah (PP) No. 62 Tahun 1990. (1990). Ketentuan Keprotokolan Mengenai Tata Tempat, Tata Upacara Dan Tata Penghormatan.

Peraturan Rektor Nomor 55 Tahun 2016. (2016). Protokoler Unpad. 